\begin{tabular}{l|l}
\hline $\begin{array}{l}\text { 2. To: (Receiving Organization) } \\
\text { Characterization Field } \\
\text { Engineering }\end{array}$ & $\begin{array}{l}\text { 3. From: (Originating Organization) } \\
\text { Process Control }\end{array}$ \\
\begin{tabular}{ll} 
5. Proj./Prog./Dept./Div.: & 6. Design Authority/ Design Agent/Cog. \\
Tank Farms & K. D. Fowler \\
\hline
\end{tabular}
\end{tabular}

8. Originator Remarks:

Transmittal of dispositions to Approved Checklist for Flammable Gas/Rotary Mode Core Sampling items.

\section{A. Design Basel ine Document? [] Yes $[X]$ No}

4. Related EDT No.:
NA
NA Purchase Order No.:

9. Equip./Component No.: NA

10. System/Bldg./Facility: 24I-TX-116

12. Major Assm. Dwg. No.:

\section{NA}

13. Permit/Permit Application No.: NA

14. Required Response Date: September 30,1998

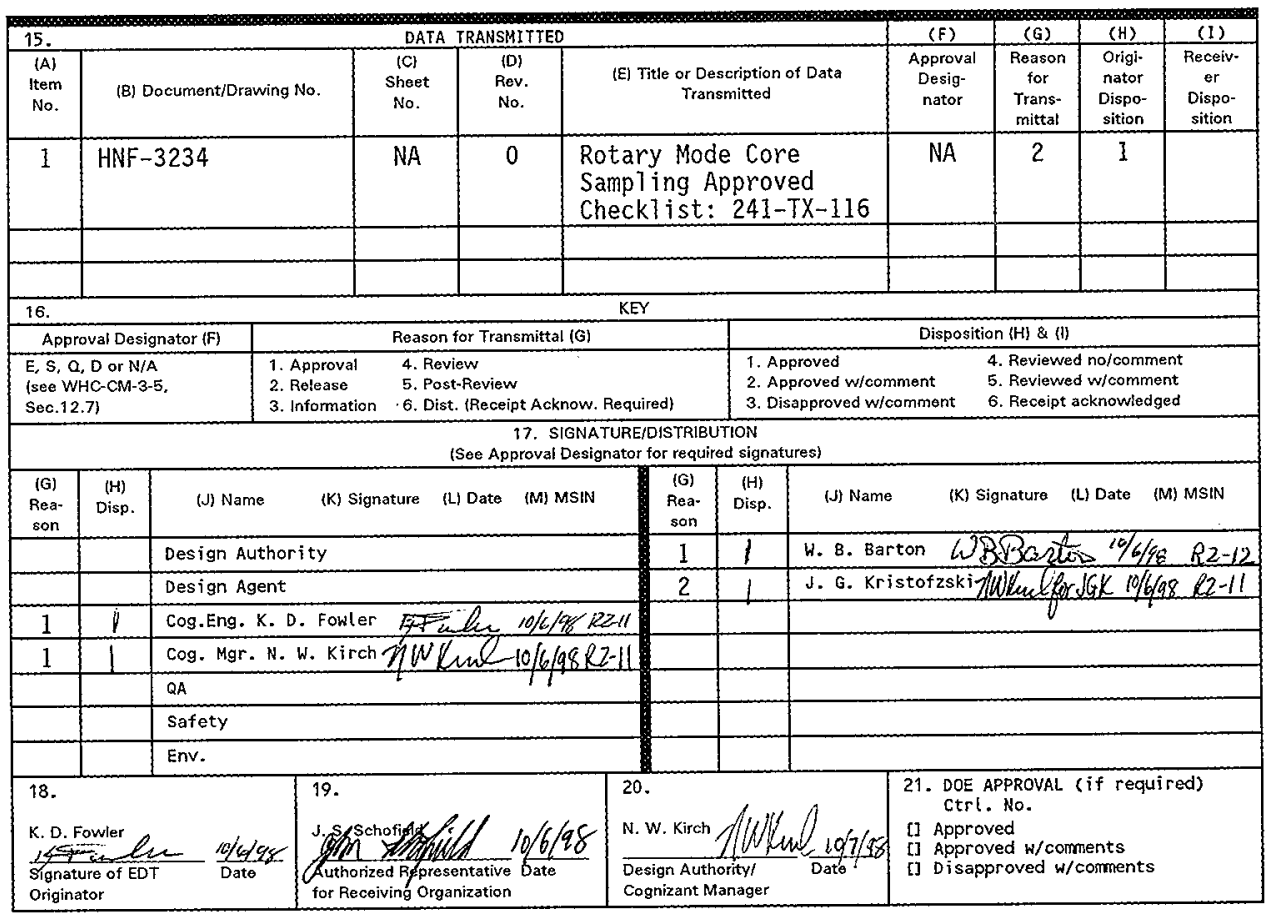




\title{
Rotary Mode Core Sampling Approved Checklist: 241-TX-116
}

\author{
K. D. Fowler
}

Lockheed Martin Hanford Corp., Richland, WA 99352

U.S. Department of Energy Contract DE-ACO6-96RL13200

EDT/ECN: 625030

Org Code: 7 Al50

B\&R Code: EW 3120074

UC: 2070

CACN/COA: $102265 / B 000$

Total Pages: 20

Key Words: flammable gas, single-she1\} tank, characterization, core sample, checklist

Abstract: The safety assessment for rotary mode core sampling was developed using certain bounding assumptions, however, those assumptions were not verified for each of the existing or potential flammable gas tanks. Therefore, a Flammable Gas/Rotary Mode Core Sampling Approved Checklist has been completed for tank 241-TX-116 prior to sampling operations. This transmittal documents the dispositions of the checklist items from the safety assessment.

TRADEMARK DISCLAIMER. Reference herein to any specific commercial product, process, or service by trade name, trademark, manufacturer, or otherwise, does not necessarily constitute or imply its endorsement, recomendation, or favoring by the United States Govermment or any agency thereof or its contractors or subcontractors.

Printed in the United States of America. ro obtain copies of this document, contact: Document Control Services, P.0. Box 950, Mailstop H6-08, Richland WA 99352, Phone (509) 372-2420; Fax (509) 376-4989.
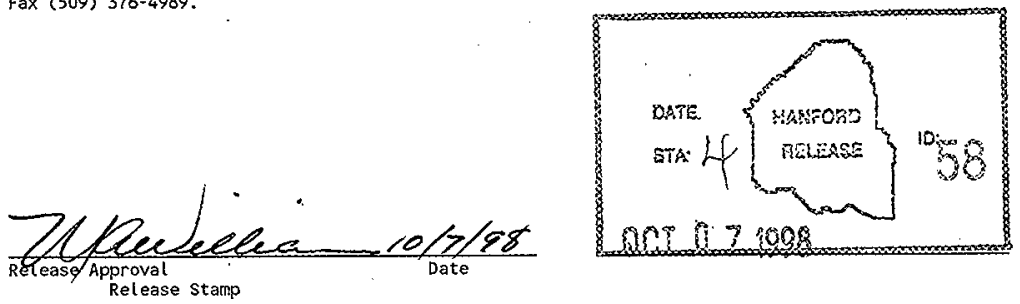

\section{Approved for Public Release}




$$
\text { HNF-3234, Rev. } 0
$$

\section{CONTENTS}

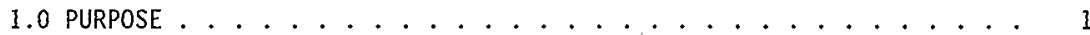

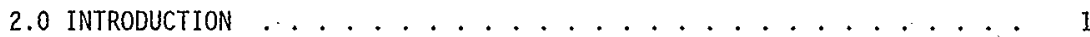

3.0 RMCS APPROVED CHECKLIST ITEMS ................ 1

3.1 Tank Specific Hazards/Other Watch Lists........... 1

3.2 Flammable Gas Composition ............... 2

3.3 Toxic Gas Composition ................. 3

3.4 Waste Temperature ............... . . 4

3.5 Waste Energetics . . . . . . . . . . . . 4

3.6 Likelihood of Gas Release Events ............ 5

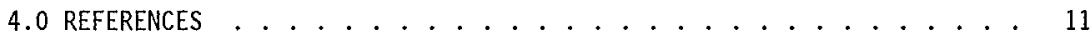


HNF-3234, Rev. 0

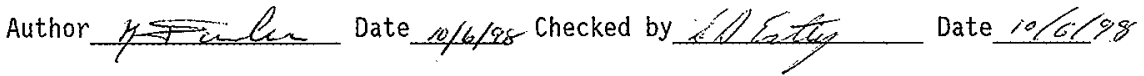

\subsection{PURPOSE}

This report provides the dispositions of each issue contained in the Flammable Gas (FG)/Rotary Mode Core Sampling (RMCS) Approved Checklist for single-shel] tank (SST) 241-TX-116.

\subsection{INTRODUCTION}

The safety assessment for RMCS (DE\&SH 1997) assessed safety aspects of the installation, operation, and removal of RMCS equipment in SSTS on the

Flammable Gas Watch List, hereafter referred to as FG/RMCS operations. The safety assessment was developed using certain bounding assumptions, however, these assumptions have not been verified for each tank. Therefore, each issue included on the FG/RMCS Approved Checklist has been evaluated for tank 241-TX-116 and the assumptions have been verified to be bounding.

This report was completed using the best available tank data as of September 17, 1998 from the Tank Characterization and Safety Resource Center (TCSRC), the Survei]lance Analysis Computer System database (SACS), and the Jank Characterization Database (TCD) via the Tank Waste Information Network system II interface (TWINS2).

\subsection{RMCS APPROVED CHECKLIST ITEMS}

\subsection{Tank Specific Hazards/0ther Watch Lists}

Issue: DE\&SH 1997 does not address ferrocyanide issues even though some of the flammable gas tanks may al so be on the Ferrocyanide Watch List. This checklist item is especially important for tanks that are on multiple Watch Lists (in addition to Flammable Gas Watch List).

Does the tank being considered for RMCS operations have a specific hazard or accident initiator that is not analyzed in Sections 3 and 4 of DE\&SH 1997?

\section{Yes}

No $\underline{X}$

If yes, the analyses in Sections 3 and 4 of DE\&SH 1997 must be supplemented to cover the tank specific conditions.

Basis: Tank 241-TX-116 has not been identified as a Watch List tank. However, controls on drill bit overheating are in place to minimize the potential for an exothermic waste reaction (DE\&SH 1997, Section 6, "Controls").

The ferrocyanide unreviewed safety question (USQ) has been closed. All open USQs regarding tank waste 1) have been addressed in the Authorization Basis documents 2) have been addressed in this check list, or 3) are not applicable. USQ Screen TF-97-0809 evaluates RMCS against applicable ignition controls. 
HNF-3234, Rev. 0

Author

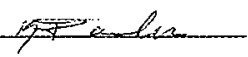

Date

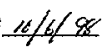

Checked by

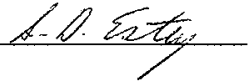

Date

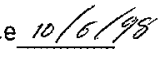

Multiple hazards were analyzed in the RMCS Safety Assessment (DE\&SH 1997). No specific hazard or accident initiator that is not analyzed in DE\&SH 1997 has been identified for this tank.

To prevent organic solvent fires which might be initiated by RMCS operations, an Ignition Control Program is required by the Basis for Interim Operation (BI0) (Leach 1997, Section 5.3.2.15). Ignition Control Program key elements are specified as sets of controls in FDH 1998. These key elements comprise intrusive controls, vehicle controls, flammable gas ignition source controls (set \#1 and set \#2), deviations from flammable gas ignition controls, compensatory ignition controls.

To assure Authorization Basis compliance during RMCS operations, applicable controls have been incorporated into the following procedures.

1) T0-020-451, Rev. D-10, "Setup and Takedown of Core Sample Systems," dated Juiy 1, 1998.

2) T0-080 518, Rev. C-14, "Core Sampling with Trucks 3 and 4 (Rotary Bit)," dated June 24, 1998.

According to Table 5.3.2.15-6 in the BIO, solvent jgnition controls are required for tank 241-TX-116 because it had not been vapor space sampled at the time Section 5.3.2.15 of the BIO was written. Tank 241-TX-116 was vapor sampled on September 18, 1997. Analys is detected $4.8 \mathrm{mg} / \mathrm{m}^{3}$ of total non methane hydrocarbon (TNMHC). Using these results and calculations Table 5.3.2.15-6 are based on, solvent ignition controls would not be required for tank 241-TX-116 (Appendix B).

\subsection{Flammable Gas Composition}

Issue: Controls for this issue have been incorporated in the BIO (Leach 1997).

Is there new information that reveals there are other flammable gas species and/or the assumed value of the lower flammability limit (LFL) is not conservative.

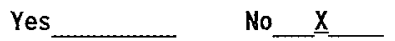

If yes, the analysis must be revised to incorporate the new data.

Basis: Tank vapor sampling/monitoring on September 18, 1997 did not identify any significant concentration of flammable gases present. The data reported in the TCD show the maximum detected concentration of $\mathrm{NH}_{3}=15$ ppmv. $\mathrm{H}_{2}, \mathrm{~N}_{2} \mathrm{O}$, and $\mathrm{CH}_{4}$ were not detected and were reported as $<50$ ppmv. Calculations using these maximum reported values show that the LFL of the $\mathrm{H}_{2}, \mathrm{CH}_{4}, \mathrm{~N}_{2} \mathrm{O}$ and $\mathrm{NH}_{3}$ mixture is $2.1 \%$ as $\mathrm{H}_{2}$ (Appendix $\mathrm{A}$ ). 
HNF-3234, Rev. 0

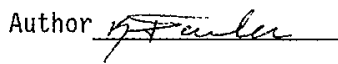

Date $10 / 6 / 98$ Checked

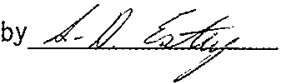

Date $10 / 6198$

There is no new information for tank 241-TX-116 that reveals that there are flammable gas species present which have not been considered in the BIO analysis or that the flammable gas composition assumed for the tank is not conservative.

\subsection{Toxic Gas Composition}

Issue: For toxic effects, the gas composition in a given gas release event (GRE) is assumed to be $60 \%$ ammonia or $75 \%$ nitrous oxide.

Has any evidence been discovered to indicate that the above values (especially the ammonia fraction) may be exceeded in the tank as a result of a new analysis or data, or that they are not conservative?

Yes

No $\underline{x}$

If yes, the consequence analysis in DE\&SH 1997 must be re-evaluated. This can be achieved by simply scaling the new data with the $60 \%$ fraction used in the consequence analysis. The consequence analys is is the linear function of gas composition; thus, simple multiplication would be used to consider different gas concentrations.

Basis: Review of tank 241-TX-116 vapor sample data, level/temperature data and fill history, indicate no reason to believe the tank should have any GRE ammonia or nitrous oxide concentrations outside of those previously observed.

The method to estimate the vapor fraction of ammonia in tank waste gas used in DE\&SH 1997 relies on either the hydrogen or nitrous oxide values. Maximum reported results for tank $241-\mathrm{TX}-116$ are:

$\begin{array}{lrc}\text { Component } & \text { Concentration } & \text { Sample Date } \\ & \cdot & \\ {\left[\mathrm{H}_{2}\right]} & <50 \mathrm{ppmv} & 9 / 18 / 97 \\ {\left[\mathrm{NH}_{3}\right]} & 15 \mathrm{ppmv} & 9 / 18 / 97 \\ {\left[\mathrm{CH}_{4}\right]} & <50 \mathrm{ppmv} & 9 / 18 / 97 \\ {\left[\mathrm{~N}_{2} \mathrm{O}\right]} & <50 \mathrm{ppmv} & 9 / 18 / 97\end{array}$

Using this data to estimate the tank waste gas composition by the method used in DE\&SH 1997. Appendix C, indicates that ammonia comprises approximately $9.1 \%$ of the tank gas and nitrous oxide comprises approximately $30.3 \%$ of the tank gas (Appendix A). 
HNF-3234, Rev. 0

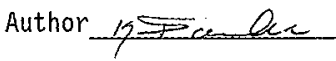

Date 10/6/98 Checked by

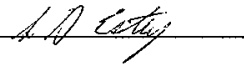

Date

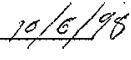

Issue: Also, results from the vapor space sampling program were reviewed. Major toxic gases that were found in the dome space of the presently defined flammable gas tanks are ammonia and nitrous oxide. Other gases are found in trace quantities and do not pose a concern. However, it was recognized that the existing data are limited and all tanks of interest are not covered.

Thus, is there any new data that reveals that toxic gases in excess of the hazardous 1 imits have been detected in the tank?

Yes

No $\underline{X}$

If yes, the consequence analysis must be re-evaluated. The re-evaluation may be done by simply scaling the toxic gas fraction and the guidelines against the ammonia fraction and the assocjated Risk Guidelines.

Basis: Tank vapor sample data from September 18, 1997 identified no toxic gases in excess of hazardous limits in tank 241-TX-116. $\mathrm{CO}_{2}$ (350 ppm), $\mathrm{H}_{2} \mathrm{O}\left(13,000 \mathrm{mg} / \mathrm{m}^{3}\right)$ were the major components identified. Sample data is available from the TCD via TWINS2.

\subsection{Waste Temperature}

Issue: Does the best available tank temperature data show that the peak waste temperature (considering uncertainties) is Tess than $90^{\circ} \mathrm{C} \cdot\left(194^{\circ} \mathrm{F}\right)$ ?

$$
\text { Yes_ } \mathrm{X}
$$

If no, (peak waste temperature $\geq 90^{\circ} \mathrm{C}$ ), the envelope testing results discusșed in DE\&SH 1997, Appendix $F$ must be re-evaluated.

Basis: Only historical temperature data from 1975 and 1977 is available from the SACS database for tank 241-TX-116. The data is plotted as temperature profiles in Figure 3 . These data show that the tank waste was below $48^{\circ} \mathrm{C}$ $\left(118^{\circ} \mathrm{F}\right)$ in 1975 and Below $32^{\circ} \mathrm{C}\left(90^{\circ} \mathrm{F}\right)$ in 1977 .

\subsection{Waste Energetics}

Issue: DE\&SH 1997, Table G-3 of Appendix G lists the frequency of waste fire accidents for the 100-series SSTs. The analysis given in Appendix $G$ is based on waste composition data through December 1995. New data taken after

December 1995 or revisions to the old database may alter the results of the analysis given in Appendix $G$.

Therefore, in using new or revised data, (taken after. December 1995), it first must be verified that the conclusions of the analysis in Appendix $G$ are not changed.

\section{Not changed $\underline{X}$ Changed}


HNF-3234, Rev. 0

Author $19 \mathrm{a}$ le Date 10/6/98 Checked by

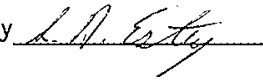
Date

Basis: Only limited historical tank waste data is available for tank 241-TX-116 from 1974 and 1981 . These samples contained from $18 \%$ to $53 \%$ water. Total organic carbon (TOC) concentrations ranged from $0.21 \mathrm{~g} / 1$ to $1 \mathrm{~g} / 1$. The data is available from TCD via TWINS2. This tank waste data does not provide evidence that the conclusions of the analysis in Appendix $G$ of DE\&SH 1997 are changed in any way.

Criteria for evaluating the possibility of a propagating exothermic reaction in Meacham, et al. 1998 are based on waste TOC concentration and percent water. The criterion states that no propagation is possible if the waste $\operatorname{TOC}(\mathrm{wt} \%)<4.5+0.17 \times\left(\mathrm{wt} \% \mathrm{H}_{3} \mathrm{O}\right)$ or if the waste contains $>20 \%$ water. Even dry materials would require $\geq 4.5 \mathrm{wt} \%$ TOC for propagation.

Additionally, according to The Organic Complexant Topical Report, Meacham, et al, 1998, the calculated reactive waste fraction in tank $241-T X-116$ is $1.6 \%$. There is $95 \%$ confidence that $98.4 \%$ of the waste in tank $241-T X-116$ contains $<4.5 \%$ TOC.

\subsection{Likelihood of Gas Release Events}

Issue: Controls for this issue have been incorporated in the BIO. The large RMCS induced GRE probability as discussed in the BIO is "not postulated." Do additional data or analyses exist for the tank to indicate that the GRE probabilities used in the BIO are not conservative?

Yes_ No_ 는

If yes, the GRE probabilities need to be re-evaluated.

Basis: The most recent tank waste data available in the TCSRC is from 1981. The most recent vapor sample data are from September 18, 1997 vapor samples (TWINS2). These data indicate that the GRE probabilities used in the BIO are conservative. Tank 241-TX-116 is a Facility Group 3 tank, which by definition, has been conservatively postulated to have the potential for only sma71 induced GREs. Large GREs from SSTs are not postulated during locally disturbing activities such as RMCS (Wagoner 1997). 
HNF-3234, Rev. 0

Author

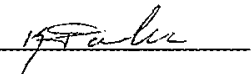

Date $10 / 6 / 0 \%$ Checked by

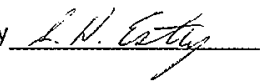

Date

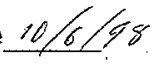

Issue: In general, before the FG/RMCS operations start on the tank, the best available tank specific data for gas inventory and gas release evidence is evaluated.

Have one or more of the following conditions been observed for the tank?

- Periodic level drops and Tevel swells in excess of \pm 3 in.

- Level drop $\geq 3$ in. during or after an intrusive event.

- Dome concentration measurements $\geq 25 \%$ of the LFL before, during or after a waste intrusive event.

- A well defined nonconvective layer (parabolic temperature profile) below a supernate or convective layer (flat temperature profile) that would be indicative of potential rollovers.

- Retained gas inventory estimates (via Tevel swe11, fill history, etc.) is greater than $20 \%$ of the available dome space volume.

Yes

No $\underline{X}$

If yes, the GRE probability model given in DE\&SH 1997, Appendix L must be re-evaluated. If the re-evaluation indicates that the existing GRE model given in DE\&SH 1997, Appendix L is not conservative for the tank, a revision to DE\&SH 1997 wi11 be necessary.

Basis: Level data from August 1, 1988 through September 24, 1998 show no periodic level drops and level swells in excess of three inches indicative of GRE behavior for tank 241-TX-116 (Figures 1 and 2). No interstitial liquid level (ILL) data is available for the tank.

The temperature profile for the tank is not indicative of potential rollovers (Figure 3). The Waste Tank Summary Report for Month Ending May 31, 1998 (Hanton 1998) states that the tank contains no supernate.

Evaluation of the tank (Hodgson et a1. 1996) indicates that the tank does not generate enough flammable gas to pose a steady state flammability hazard. The results from flammable gas monitoring performed September 18, 1997 indicated $<0.5 \%$ of the LFL. In addition, Stauffer 1997, indicates that the tank headspace will not reach $25 \%$ of the $L F L$.

No correlation between the inverse of atmospheric pressure and tank waste level data was identified for tank 241-TX-116. Evaluation of surface level data indicated the potential presence of trapped gas which could cause the tank headspace to reach approximately $0 \%$ of the $L F L$ under GRE conditions (Hodgson et a7. 1996). 
HNF-3234, Rev. 0

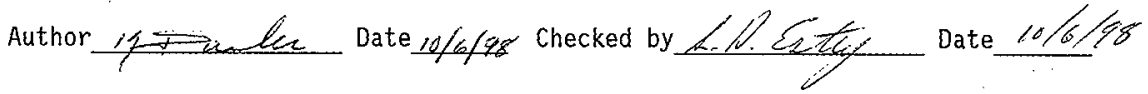

The calculated available tank dome space volume is $65,110 \mathrm{ft}^{3}$. This is obtained from the total tank volume minus the waste volume calculated from the September 20, 1998 surface level reading, 212.51 inches.

$$
\begin{aligned}
& \text { waste volume }(\text { gal })=[\text { waste } 3 \text { eve } 1 \text { (in })-12 \text { in }] * 2754 \text { gal } / \text { in }+12,500 \text { gal } \\
& =(212.51-12) * 2754+12,500 \\
& \approx 564,705 \mathrm{gal}\left(75,490 \mathrm{ft}^{3}\right) \\
& 140,600 \mathrm{ft}^{3}-75,490 \mathrm{ft}^{3} \quad \approx 65,110 \mathrm{ft}^{3} \\
& \text { (tank volume - waste volume } \quad=\text { available dome space) }
\end{aligned}
$$

$20 \%$ of the headspace is $13,022 \mathrm{ft}^{3}$. The tank flammable gas evaluation (Hodgson et al. 1996) identified no significant retained gas inventory has been estimated for this tank. 
HNF-3234, Rev. 0

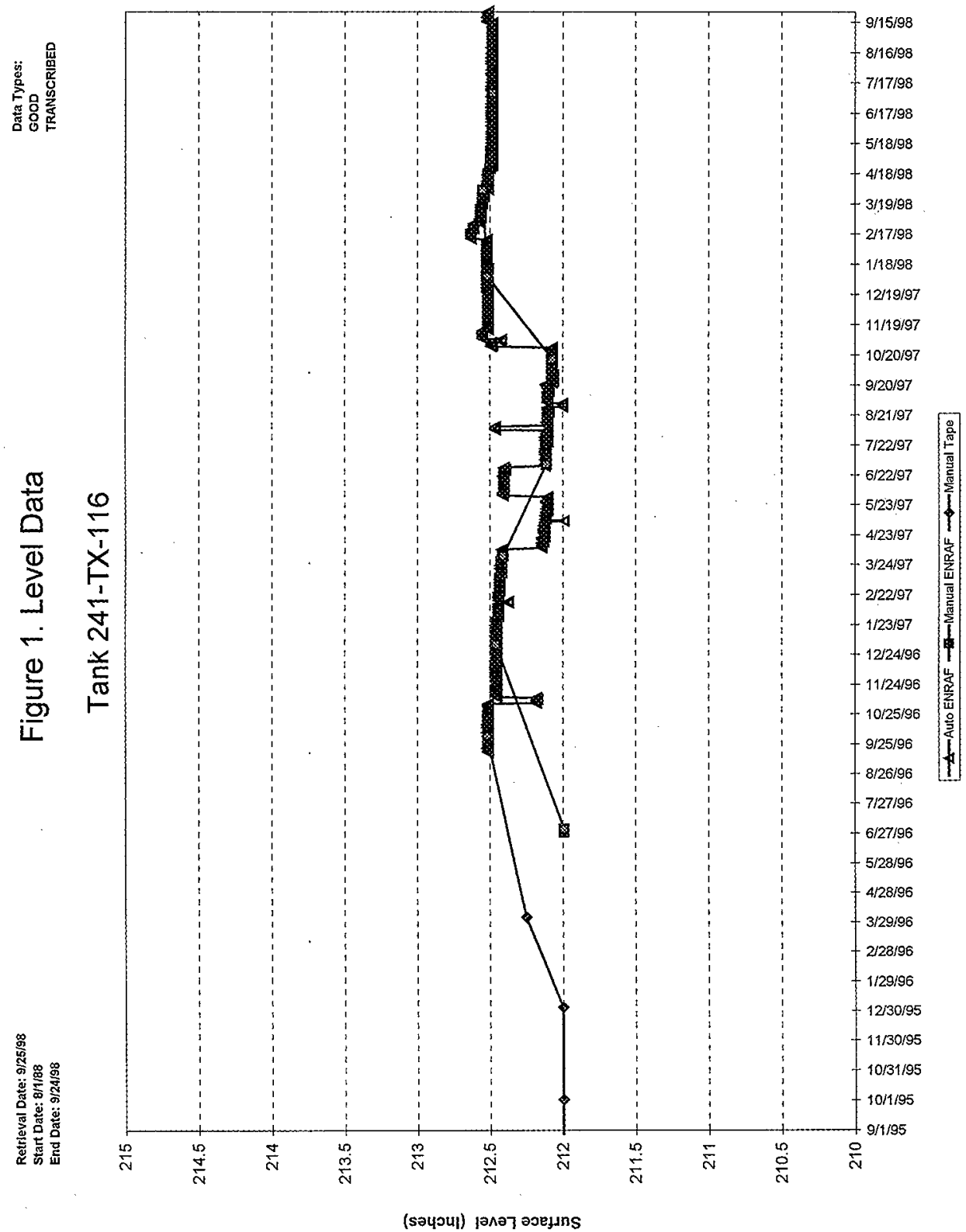


HNF-3234, Rev. 0

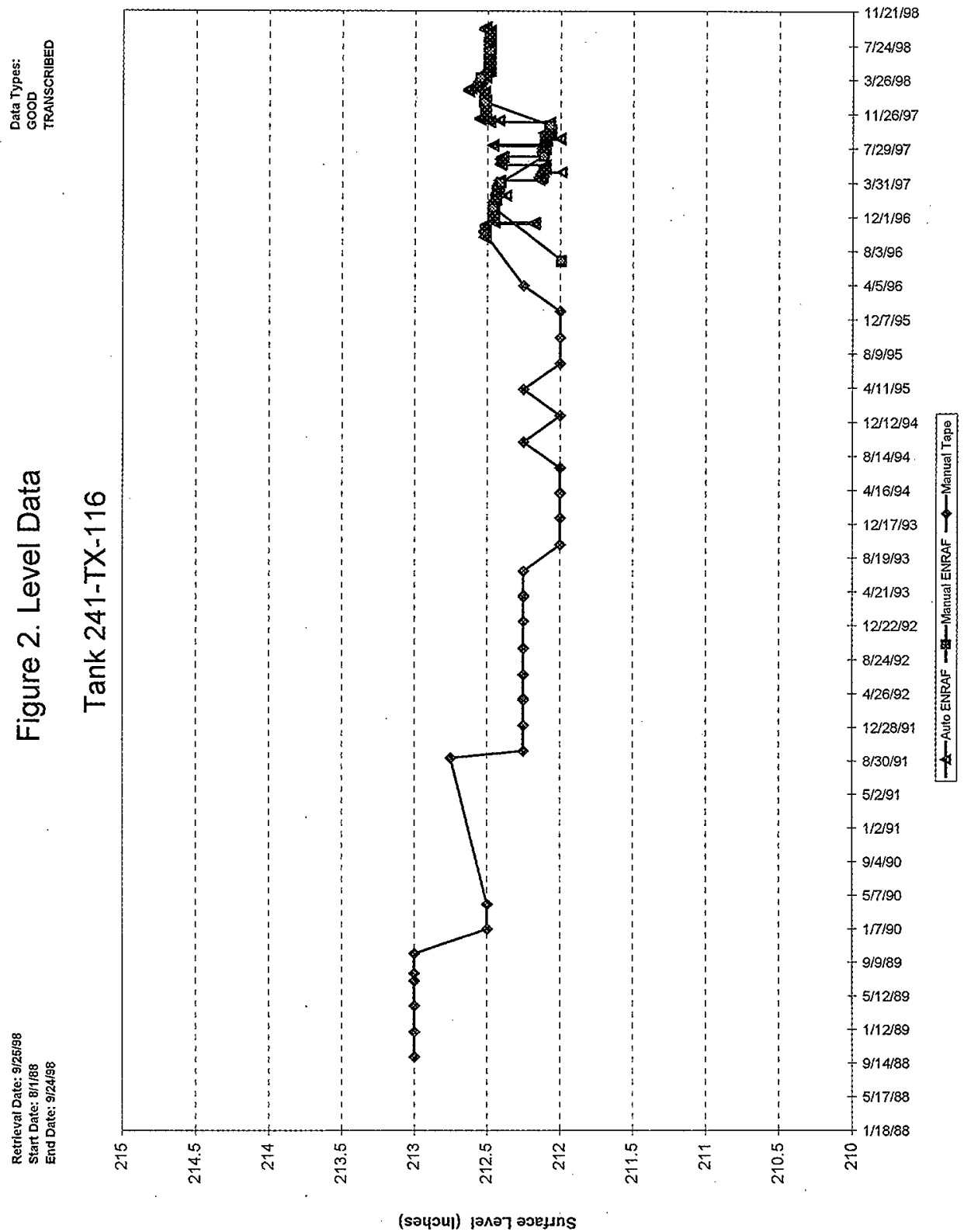




\section{Figure 3. Temperature Profiles}

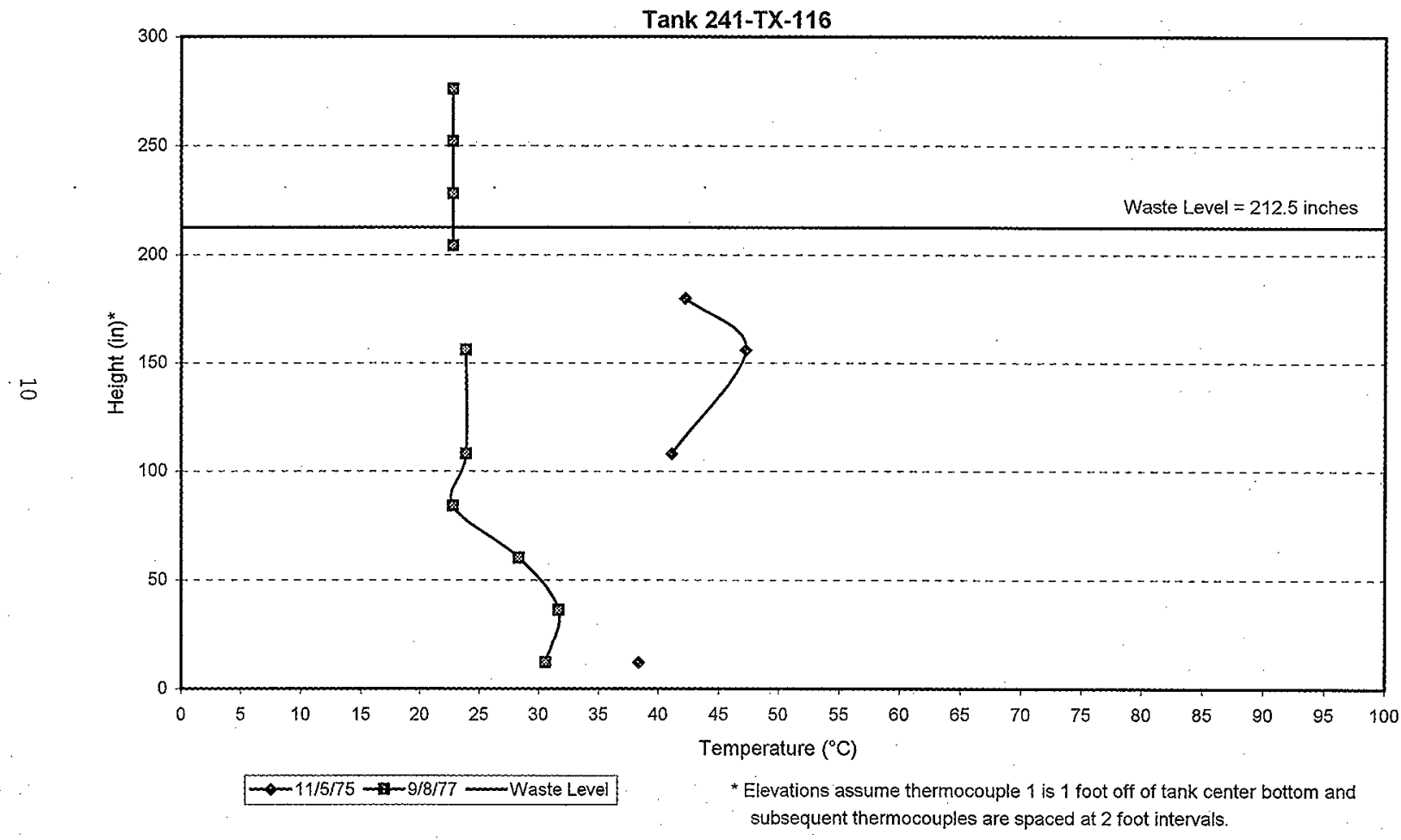




\subsection{REFERENCES}

DE\&SH, 1997, "A Safety Assessment of Rotary Mode Core Sampling in Flammable Gas Single-Shel1 Tanks," Hanford Site, Richland, Washington, WHC-SD-WM-SAD-035, Rev, 0-b, DE\&S Hanford, Richland, Washington.

FDH, 1998, "Tank Waste Remediation System Technical Safety Requirements," HNF-SD-WM-TSR-006, Rev, 0-J, Fluor Daniel Hanford, Inc., Richland, Washington.

Hanlon, B. M., 1998, "Waste Tank Summary Report for Month Ending May 31, 1998," HNF-EP-0182-122, Lockheed Martin Hanford Corp., Richland, Washington.

Hodgson, K. M., R. P. Anantatmula, S. A. Barker, K. D. Fowler, J. D. Hopkins, H. A. Lechelt, D. A Reynolds, D. C. Hedengren, R. E. Stout, and R. T. Winward, March 1996, "Evaluatjon of Hanford Tanks for Trapped Gas, "WHC-SD-WM-ER-526, Rev. 1, Westinghouse Hanford Company, Richland, Washington.

Leach, C. E., 1997, "Tank Waste Remediation System Basis for Interim Operation," HNF-SD-WM-BI0-001, Rev. O-A, DE\&S Hanford Inc., Richland, Washington.

Meacham, J. E., W. L. Cowley, A. B. Webb, N. W. Kirch, J. A. Lechelt, D. A. Reynolds, L. A. Stauffer, D. B. Bechtold, D. M. Camaioni, F. Gao, R. T. Hallen, and P. G. Heasler, J. L. Huckaby, R. D. Scheele, C. S. Simmons, J. J. Toth, and L. M. Stock, 1998 "Organic Complexant Topical Report," HNF-SD-WM-CN-058, Revision 2 Final Draft, DE\&S Hanford Inc:, Richland, Washington.

Stauffer, L. A., 1997, "Calculation Note: Hydrogen Generation Rates at SteadyState Flammable Gas Concentrations for Single-Shell Tanks," HNF-SD-WM-CN-116, Rev. 0-A, Lockheed Mart in Hanford Company, Richland, Washington.

Wagoner, J. D., 1997, letter to H. 3. Hatch, President, FDH, "Contract Number DE-AC06-96RL13200 - Approval of Rotary Mode Core Sampling (RMCS) Authorization Bas is Change Request," DOE-RL: 97-WSD-165, Incoming: 9755946, dated July 8, 1997. 
HNF-3234, Rev. O

\section{APPENDIX A}

Supporting Calculations for HNF-3234

Consisting of 3 pages

including this cover sheet

A-1 


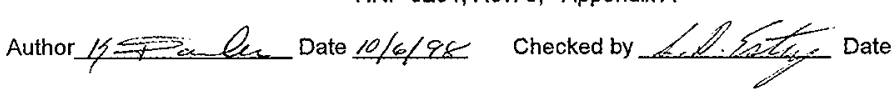

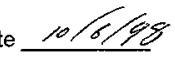

$\mathrm{X} i=$ vapor fraction of component $\mathrm{i}$

$\mathrm{nc}=$ non-condensable vapor $\left(\mathrm{H}_{2}, \mathrm{CH}_{4}, \mathrm{~N}_{2} \mathrm{O}\right)$

condensable vapor $=\mathrm{NH}$

Maximum sampling/monitoring values (ppmv) - August 6, 1997 from TCD

$$
\mathrm{H}_{2}:=50 \quad \mathrm{CH}_{4}:=50 \quad \mathrm{~N} 2 \mathrm{O}:=50 \quad \mathrm{NH}_{3}:=15
$$

\section{Calculate Xnc,i for each nc gas}

$$
\begin{array}{lll}
\mathrm{X}_{\mathrm{ncH} 2}:=\frac{\mathrm{H}_{2}}{\mathrm{H}_{2}+\mathrm{CH}_{4}+\mathrm{N} 2 \mathrm{O}} & \mathrm{X}_{\mathrm{ncN} 2 \mathrm{O}}:=\frac{\mathrm{N} 2 \mathrm{O}}{\mathrm{H}_{2}+\mathrm{CHI} 4+\mathrm{N} 2 \mathrm{O}} & \mathrm{X}_{\mathrm{ncCH} 4}:=\frac{\mathrm{CH}_{4}}{\mathrm{H}_{2}+\mathrm{CII}_{4}+\mathrm{N} 2 \mathrm{O}} \\
\mathrm{X}_{\mathrm{ncH} 2}=0.333 & \mathrm{X}_{\mathrm{ncN} 2 \mathrm{O}}=0.333 & \mathrm{X}_{\mathrm{ncCH} 4}=0.333
\end{array} .
$$

Calculate the $\mathrm{NH}_{3}$ fraction in release gas

From equation C-4 from DE\&SH 1997

$$
\mathrm{S} 1:=\mathrm{X}_{\mathrm{ncH} 2} \cdot \frac{\mathrm{NH}_{3}}{\mathrm{H}_{2}} \quad \mathrm{XNH}_{3}:=\frac{\mathrm{S} 1}{\mathrm{~S} 1+1} \quad \mathrm{XNH}_{3}=0.091 .
$$

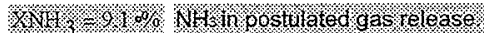

\section{Estimate overall waste gas composition}

Volume fraction, $X$, of component, $i$

Given: $\mathrm{XNH}_{3}=0.091$ from above,

$$
\begin{array}{lll}
\mathrm{XH}_{2}:=\left(1-\mathrm{XNH}_{3}\right) \cdot \mathrm{X}_{\mathrm{nc} 2} & \mathrm{XH}_{2}=0.303 & 30.3 \% \\
\mathrm{XN}_{2} \mathrm{O}:=\left(1-\mathrm{XNH}_{3}\right) \cdot \mathrm{X}_{\mathrm{nCN} 2 \mathrm{O}} & \mathrm{XN}_{2} \mathrm{O}=0.303 & 30.3 \% \\
\mathrm{XCH}_{4}:=\left(1-\mathrm{XNH}_{3}\right) \cdot \mathrm{X}_{\mathrm{ncCH} 4} & \mathrm{XCH}_{4}=0.303 & 30.3 \%
\end{array}
$$

Calculate LFL in terms of hydrogen concentration

Equation C-7 from DE\&SH 1997 a

$$
\mathrm{LFL}:=\frac{1}{\frac{1}{.04}+\frac{\mathrm{XNH}_{3}}{.15}+\frac{\mathrm{XCH}_{4}}{\mathrm{XH}_{2}}} \quad \mathrm{LFL}=0.021 \text { or } 2.1 \% \text { as } \mathrm{H}_{2}
$$




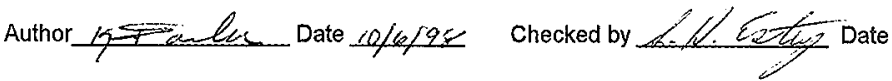

$\% \mathrm{H}_{2} \mathrm{O}$ and max. TOC reported TCD Historical data.

$$
\begin{aligned}
& \rho_{1}=1.387 \\
& \text { TOC }=1 \mathrm{~g} / \mathrm{L} \quad \text { TOC }_{\max 1}:=\frac{1 \frac{\mathrm{g}}{\mathrm{L}}}{1387 \cdot \frac{\mathrm{g}}{\mathrm{L}}}
\end{aligned}
$$

Percent Water $=18.5(\mathrm{~min}$. value $)$ to $53(\max$. value $)$

Max.Water fraction, $\mathrm{H}_{2} \mathrm{O}_{1}:=0.53$

$\max w t \% \mathrm{TOC}_{1}$ based on $^{\mathrm{TOC}_{\max 1}} \quad \mathrm{TOC}_{1}:=\mathrm{TOC}_{\max 1} \quad \mathrm{TOC}_{1}=0.072 \circ \%$

Dry wt. basis calculations

$\mathrm{TOC}_{\mathrm{DW}}=$ percent $\mathrm{TOC}$ dry wt. basis

$$
\operatorname{TOC}_{D W 1}:=\frac{\operatorname{TOC}_{1}}{1-\mathrm{H}_{2} \mathrm{O}_{1}} \quad \operatorname{TOC}_{\mathrm{DW1}}=0.15 \%
$$

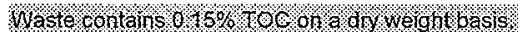

Tank Headspace Calculations

$$
\begin{aligned}
& L w=\text { waste level } \\
& V w=\text { waste volume } \\
& V h=\text { headspace volume } \\
& V r g=\text { retained gas volume }
\end{aligned}
$$

$$
\begin{array}{ll}
\mathrm{L}_{\mathrm{W}}:=212.51 \cdot \mathrm{in} & \mathrm{ft} 3:=7.4805 \cdot \mathrm{gal} \\
\mathrm{V}_{\mathrm{W}}:=\left[\left(\mathrm{L}_{\mathrm{W}}-12 \cdot \mathrm{in}\right) \cdot 2754 \frac{\mathrm{gal}}{\mathrm{in}}\right]+12500 \mathrm{gal} & \mathrm{V}_{\mathrm{w}}=5.647 \cdot 10^{5} \text { ogal } \\
& \mathrm{V}_{\mathrm{w}}=7.549 \cdot 10^{4} \text { of } 3 \\
\mathrm{~V}_{\mathrm{h}}:=140600 \cdot \mathrm{ft} 3-\mathrm{V}_{\mathrm{w}} & \mathrm{V}_{\mathrm{h}}=6.511 \cdot 10^{4} \text { of } 3
\end{array}
$$


HNF-3234, Rev. 0

\section{APPENDIX B}

Organic Solvent Ignition Control Determination CaTculations

Consisting of 4 pages

including this cover sheet 


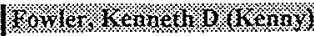

From: Huckaby, James L [jim.huckaby@pnl.gov]

Sent: Tuesday, September 01, 1998 10:43 AM

To: Fowler, Kenneth D (Kenny)

Subject: RE: TX-116 data

Kenny,

The TCD curator had fixed the miscalculated average, and i was able to quickly get the numbers (less than a half hour). I did correct for the fraction of semivolatiles using the same method as in last year's report. The vapor samples were virtually devoid of semivolatiles, which results in a very small estimated pool size. There are apparently no TC tree data for this tank, at least nothing was available on the TCD.

$\operatorname{Jim}$

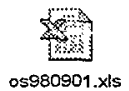

....-Original Message-...-

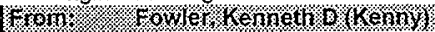

Sent: Tuesday, September 01, 1988 9:56 AM

To: $\quad$ Huckaby, James L

Subject: RE: TX-116 data

Jim,

If you can correct T-116 we'd appreciate it. Let me know if you need a Work Order and how much.

Thanks,

Kenny

-...-Original Message......

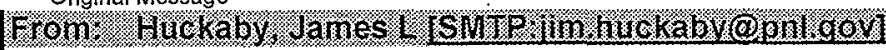

Sent: Wednesday, August 26, 1998 12:34 PM

To: $\quad$ Fowler, Kenneth D (Kenny)

Subject: TX-116 data

Kenny,

The attached spreadsheet gives organic pool estimates for $T X-116$ and $T X-118$. The Tank Characterization Database (TCD) has an apparent error in the calculation of average concentrations, so I have eliminated the summation of organic compounds in SUMMA samples (column $\mathrm{K}$ ). It is possible for me to calculate the numbers independent of the database, but not on my lunch hour (too time consuming). I have contacted the TCD vapor data care-taker and when she returns next week she'll fix the problem. I am sure that when all corrections are made to the $T C D$, and 1 correct for the fraction of volatile compounds, the estimated pool size in TX-116 would be smaller than indicated in the attached. However, uniess I hear from you that this is necessary, I'm not going to recalculate the values. 
HNF-3234 Rev. 0

16txorganpool.xls

\begin{tabular}{|c|c|c|c|c|c|c|c|c|c|c|c|c|c|c|c|c|c|c|c|c|}
\hline & Tank & $\begin{array}{c}\text { Dale } \\
\text { Sampled }\end{array}$ & $\begin{array}{l}\text { Headspace } \\
\text { Temperature } \\
\text { (C) }\end{array}$ & $\begin{array}{c}\text { TC Tree } \\
\text { Headspace } \\
\text { Temperature } \\
\text { (C) }\end{array}$ & $\begin{array}{c}\text { Headspace } \\
\text { pressure } \\
\text { (forr) }\end{array}$ & $\begin{array}{l}\text { ORNL } \\
\text { TST } \\
\text { Sum }\end{array}$ & $\begin{array}{l}\text { PNNL } \\
\text { TST } \\
\text { Sum }\end{array}$ & $\begin{array}{l}\text { PNNL } \\
\text { SUMMA } \\
\text { Sum }\end{array}$ & $\begin{array}{l}\text { SAS } \\
\text { TST } \\
\text { Sum }\end{array}$ & $\begin{array}{c}\text { SAS } \\
\text { SUMMA } \\
\text { Sum }\end{array}$ & $\begin{array}{c}\text { TO-12 } \\
\text { TAMHC }\end{array}$ & $\begin{array}{c}\text { ORNL } \\
\text { TST Sum }\end{array}$ & $\begin{array}{l}\text { PNNL. } \\
\text { TST SUm }\end{array}$ & $\begin{array}{l}\text { PNNL } \\
\text { SUMMA } \\
\text { Sum }\end{array}$ & $\begin{array}{c}\text { SAS } \\
\text { TST Sum }\end{array}$ & $\begin{array}{l}\text { SAS } \\
\text { SUMMA } \\
\text { Sum }\end{array}$ & $\begin{array}{c}\text { TO-12 } \\
\text { TNMHC }\end{array}$ & $\begin{array}{c}\text { Max } \\
\text { TNMOC }\end{array}$ & $\underset{\operatorname{Tin}}{\operatorname{Min}(\mathrm{C})}$ & $\begin{array}{l}\text { Fraction of } \\
\text { semivol's( }^{(1)}\end{array}$ \\
\hline 36 & C103 & May-94 & 38.0 & 38.8 & 740.0 & 2139 & na & na & na & $n a$ & $\$ 20$ & 1828 & na & na & $\mathrm{na}$ & na & 444 & 1828 & 38 & 0.80 \\
\hline 37 & C107 & $9 / 29 / 94$ & 45.9 & 46.4 & 737.7 & 4.4 & na & 7.1 & na & na & 3.6 & 3.7 & na & 5.9 & $\mathrm{na}$ & na & 3.0 & 5.9 & 45.9 & na \\
\hline$*$ & C107 & $1 / 17 / 96$ & 41.5 & 42.4 & 747.9 & na & na & na & na & $\mathrm{na}$ & 36 & na & na & na & na & na & 3.1 & 3.1 & 41.5 & na \\
\hline$\pi$ & C107 & $3 / 26 / 96$ & 39.8 & 40.2 & 743.2 & na & na & na & na & na & 2.8 & na & na & na & na & na & 2.4 & 2.4 & 39.8 & na \\
\hline$*$ & C107 & $9 / 5 / 96$ & 44.1 & 43.1 & 743.1 & na & na & na & na & na & 3.4 & na & na & na & na & na & 2.9 & 2.9 & 43.1 & na \\
\hline 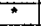 & C107 & $12 / 17 / 96$ & 42.5 & 41.3 & 765.4 & $\mathrm{na}$ & na & $n a$ & na & $n a$ & 3.8 & na & na & na & na & na & 3.3 & 3.3 & 41.3 & na \\
\hline \pm & C107 & $2 \sqrt{7} 197$ & 39.9 & 38.6 & 755.1 & $n a$ & na & na & na & $\mathrm{na}$ & 3.7 & na & $\mathrm{na}$ & na & na & na & 3.2 & 3.2 & 38.6 & na \\
\hline 38 & $\mathrm{C} 108$ & $8 / 5194$ & 24.7 & 25 & 742.0 & na & 1.4 & 0.37 & na & na & 0.35 & na & 1.3 & 0.3 & $\mathrm{na}$ & na. & 0.3 & 1.3 & 24.7 & na \\
\hline 39 & C109 & $8 / 10 / 94$ & 27.0 & 27.1 & 744.0 & 1.8 & na & 0.4 & na & $\mathrm{na}$ & 0.65 & 1.6 & $\mathrm{na}$ & 0.3 & na & $\mathrm{na}$ & 0.6 & 1.6 & 27 & na \\
\hline 40 & C110 & $8 / 18 / 94$ & 21.9 & 22.7 & 743.3 & 28 & na & 5.6 & na & na & 22 & 25 & na & 5.1 & $n a$ & na & 20 & 25 & 21.9 & 0.66 \\
\hline 41 & C111 & $9 / 13 / 94$ & 26.6 & 26.4 & 741.3 & 1.2 & na & 0.59 & na & na & 0.18 & 1.1 & na & 0.5 & na & na & 0.2 & 1.1 & 26.4 & na \\
\hline 42 & $\mathrm{C} 112$ & $8 / 11 / 94$ & 28.0 & 28.1 & 741.0 & 6.3 & na & 3 & na & na & 3.4 & 5.6 & na & 2.7 & na & na & 3.0 & 5.6 & 28 & na \\
\hline 43 & $\mathrm{C} 201$ & $6 / 19 / 96$ & 15.2 & 16.1 & 743 & na & na & na & na & na & 6.3 & na & na & $\overline{n a}$ & na & na & 5.8 & 5.8 & 15.2 & $n a$ \\
\hline 44 & C202 & $6 / 25 / 96$ & 19.6 & 16.3 & 739.9 & na & na & $\mathrm{na}$ & na & na & 2.5 & $n a$ & na & na & $n a$ & na & 2.3 & 23 & 16.3 & $n a$ \\
\hline 45 & C204 & 712196 & 17.8 & na & 735.6 & na & 36 & 218 & na & na & 161 & na & 33 & 198 & na & $n a$ & 146 & 198 & 17.8 & 0.88 \\
\hline 46 & 5101 & $6 / 6 / 96$ & 30.4 & 30.8 & 744.2 & na & 13 & 15 & na & na & 83 & na & 12 & 13 & na & na & 7.3 & 13 & 30.4 & na \\
\hline 47 & $\$ 102$ & $3 / 14 / 95$ & 24.3 & 24.2 & 741.2 & 10 & na & 21 & na & na & na & 9.0 & na & 18 & na & na & na & 18 & 24.2 & 0.03 \\
\hline$\div$ & $\$ 102$ & $1 / 26 / 96$ & 19 & 25.8 & 748.7 & na & na & na & na & na & 16 & na & na & na & na & $n a$ & 15 & 15 & 19 & 0.03 \\
\hline 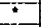 & $\$ 102$ & $4 / 4 / 96$ & 23.1 & 24.1 & 753.3 & $\mathrm{na}$ & na. & $\mathrm{na}$ & na & na & 16 & na & na & na & na & na & 15 & 15 & 23.1 & 0.03 \\
\hline$*$ & 5102 & $9 / 19 / 96$ & 28.5 & 29 & 745.0 & na & na & na & $\mathrm{na}$ & $\mathrm{na}$ & 27.5 & na & na & na & $n a$ & na & 24 & 24 & 28.5 & 0.03 \\
\hline$*$ & $\mathrm{~S} 102$ & $12 / 19 / 86$ & 26.3 & 26.5 & 753.6 & na & na & na & na & na & 17 & na & na & na & na & na & 15.4 & 15.4 & 26.3 & 0.03 \\
\hline$\pi$ & 5102 & $2 / 11 / 97$ & 22.5 & 23.9 & 749.0 & na & na & na & na & na & 19.46 & $\mathrm{na}$ & na & na & na & na & 17.7 & 17.7 & 22.5 & 0.03 \\
\hline 48 & $S+03$ & $6 / 12 / 96$ & 22.6 & 23.7 & 742.4 & na & 13.0 & 7.2 & na & na & 2.7 & $\mathrm{na}$ & 11.7 & 6.5 & na & na & 2.4 & 11.7 & 22.6 & 0.07 \\
\hline 49 & $\$ 105$ & $12 / 7 / 95$ & 21.7 & 23 & 748.4 & 2.7 & na & na & $n a$ & na & 2.5 & 2.5 & na & na & na & na & 2.3 & 2.5 & 21.7 & na \\
\hline 50 & S106 & $6 / 13 / 96$ & 19.1 & 19.4 & 740.2 & nà & $14^{\circ}$ & 9.2 & na & $\mathrm{na}$ & 3.9 & na & 13 & 8.4 & $\mathrm{na}$ & na & 3.6 & 13 & 19.1 & 0.15 \\
\hline 51 & 5107 & $6 / 18 / 96$ & 26.6 & 27.8 & 745.2 & na & $\mathrm{na}$ & na & na & na & 7.1 & na & na & na & $\mathrm{na}$ & na & 6.3 & 6.3 & 26.6 & na \\
\hline 52 & $S 108$ & $12 / 6 / 95$ & 22.6 & 22.1 & 750.8 & 0.86 & na & $n a$ & na & na & 2.6 & 0.9 & na & na & na & na & 2.4 & 2.4 & 22.1 & $n a$ \\
\hline 53 & $\$ 109$ & $6 / 4196$ & 20.5 & 18.8 & 741.9 & na & na & na & $n a$ & na & 3.7 & na & na & na & $\mathrm{na}$ & na & 3.4 & 3.4 & 18.8 & na \\
\hline 54 & $\$ 110$ & $12 / 5 / 95$ & 26.2 & 27.7 & 748.8 & 2.9 & na & na. & na & na & 3.8 & 2.6 & $\mathrm{na}$ & na & $\mathrm{na}$ & $\mathrm{na}$ & 3.4 & 3.4 & 26.2 & na \\
\hline 55 & $\mathrm{~s} 111$ & $3 / 21 / 95$ & 23.0 & 21.4 & 731.2 & 2 & $\mathrm{na}$ & 2 & $\mathrm{Ba}$ & na & na & 1.8 & na & 1.8 & na & $\mathrm{na}$ & na & 1.8 & 21.4 & na \\
\hline 56 & $\$ 112$ & $7 / 11 / 95$ & 30.8 & 20 & 742.9 & na & 5.0 & 5.9 & $\mathrm{na}$ & na & 8.2 & na & 4.6 & 5.3 & na & na & 7.5 & 7.5 & 20 & 0.01 \\
\hline 57 & 7104 & $27 / 96$ & 14.3 & 15.1 & 740.5 & na & na & 1.9 & $\mathrm{na}$ & na & 1.9 & $\mathrm{na}$ & na & 1.8 & $\mathrm{na}$ & $\mathrm{na}$ & 1.8 & 1.8 & 14.3 & na \\
\hline 58 & $T 107$ & $1 / 18 / 95$ & 21.3 & 17.4 & 742.8 & 1.5 & $\mathrm{na}$ & 3.9 & na & na & na & 1.4 & na & 3.6 & na & $\mathrm{na}$ & na & 3.6 & 17.4 & na \\
\hline 59 & $\mathrm{~T} 110$ & $8 / 31 / 95$ & 18.6 & 19.9 & 744.5 & na & 0.6 & 0.14 & $\mathrm{na}$ & $\mathrm{na}$ & 1.1 & na & 0.6 & 0.1 & na & $\mathrm{na}$ & 1.0 & 1.0 & 18.6 & na \\
\hline 60 & T111 & $1 / 20 / 95$ & 15.4 & 16.1 & 747.1 & 24 & na & 22 & na & na & na & 23 & $\mathrm{na}$ & 20 & na & na & na & 23 & 15.4 & 0.93 \\
\hline 61 & XX104 & $5 / 5 / 97$ & 15.2 & 16.7 & 743.2 & na. & $n a$ & na & 0.786 & 1.5 & 0.21 & na & na & $\mathrm{na}$ & 0.7 & 1.4 & 0.2 & 1.4 & 15.2 & na \\
\hline 62 & $1 \times 105$ & $12 / 20 / 94$ & 24.8 & 25.7 & 740.0 & 1.3 & na & 5.2 & na & na & na & 1.2 & na & 4.6 & na & na & $\mathrm{na}$ & 4.6 & 24.8 & na \\
\hline 63 & $T \times 106$ & $3 / 5 / 97$ & 18.1 & 19.9 & 746.5 & na & na & na & 6.1 & 4.5 & 1.6 & na & na & na & 5.6 & 4.1 & 1.5 & 5.6 & 18.1 & na \\
\hline 64 & TX111 & $10 / 12 / 95$ & 22.6 & 19.6 & 749.5 & 12 & na & 16 & na & na & 16 & 11 & na. & 15 & na & na & 15 & 15 & 19.6 & 0.04 \\
\hline 65 & TX113 & $8 / 6 / 97$ & 18.0 & 19.1 & 742.4 & na & na & na & 4.5 & 8.4 & 0.81 & na & na & na & 4.1 & 7.7 & 0.7 & 7.7 & 18 & 0.01 \\
\hline 66 & $7 \times 114$ & $3 / 25 / 97$ & 16.4 & na & 744.5 & na & na & na & 12 & 9.5 & 3 & na & na & na & 11.1 & 8.8 & 2.3 & 11.1 & 16.4 & 0.11 \\
\hline 67 & $T \times 16$ & $\alpha 9 / 18 / 977$ & 230 & nan & 7386 & Sa: & $n a$ & $\mathrm{ma}$ & 86 & 15 & 520 & na & $n d$ & $\mathrm{na}$ & 78 & 135 & 48 & 135 & 215 & 6048 \\
\hline 68 & $T \times 118$ & $12 / 16 / 94$ & 21.5 & 22 & 742.0 & 6.4 & na & 11 & na & na & 9.2 & 5.8 & na & 10 & na & na & 8.3 & 10 & 21.5 & 0.13 \\
\hline 69 & TY101 & $4 / 6 / 95$ & 15.6 & 16.6 & 737.3 & 1.3 & na & 1.6 & na & $n a$ & $n a$ & 1.2 & na & 1.5 & na & na & na & 1.5 & 15.6 & na \\
\hline 70 & TY102 & $4 / 12 / 96$ & 13.7 & 14.6 & 741.3 & na & 0.97 & 0.96 & na & na & 0.35 & na & 0.9 & 0.9 & na & na & 0.3 & 0.9 & 13.7 & na \\
\hline 71 & TY103 & $4 / 11 / 95$ & 15.9 & 16.4 & 745.9 & 65 & na & 32 & na & na & na & 60 & na & 30 & na & $n a$ & na & 60 & 15.9 & 0.97 \\
\hline 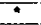 & Tr103 & $11 / 22 / 96$ & 18.5 & 19.1 & 738.1 & $\mathrm{na}$ & 12 & 84 & na & na & 46 & na & 10.9 & 76.4 & na & na & 41 & 76 & 18.5 & 0.97 \\
\hline 72 & TY104 & $4 / 27 / 95$ & na & 16.3 & 736.9 & 3.1 & na & 1.7 & na & na & $\mathrm{na}$ & 2.8 & na & 1.6 & na & na & $\mathrm{na}$ & 2.8 & 16.3 & na \\
\hline 73 & U103 & $2 / 15 / 95$ & 29.0 & 21.8 & 736.8 & 7.7 & na & 11 & na. & $\mathrm{na}$ & na & 6.4 & na & 9.9 & na & na & $\mathrm{na}$ & 9.9 & 21.8 & 0.04 \\
\hline
\end{tabular}


HNF-3234 Rev, 0

16 txorganpool.xis

\begin{tabular}{|c|c|c|c|c|c|c|c|c|c|c|c|c|c|}
\hline Tank & $\begin{array}{c}\text { Date } \\
\text { Sampled }\end{array}$ & $\begin{array}{c}\text { Ventilation } \\
\text { Rate, } Q \\
(\mathrm{~m} 3 / \mathrm{h})\end{array}$ & $\begin{array}{l}\text { Max Obs'd } \\
\text { Semivol } \\
\text { Conc. Cobs } \\
\text { (mg/m3 at } \\
\text { tank P \& T) }\end{array}$ & $\begin{array}{c}\text { Calc'd } \\
\text { Saturation } \\
\text { Conc. } \\
\text { Csat } \\
\text { (mg/m } 3 \text { ) }\end{array}$ & $\begin{array}{c}\text { Mass } \\
\text { Transfer } \\
\text { Coeff, k } \\
(\mathrm{m} / \mathrm{h})\end{array}$ & $\begin{array}{c}\text { Best } \\
\text { Estimate } \\
\text { (m2) }\end{array}$ & $\begin{array}{c}\text { Surface } \\
\text { Area }>1 \\
\mathrm{~m} 2 ?\end{array}$ & $\begin{array}{c}\text { Ventilation } \\
\text { Rate } \\
\text { Variance } \\
\text { Term }\end{array}$ & $\begin{array}{c}\text { Max. Obs'd } \\
\text { Semivol } \\
\text { Conc } \\
\text { Variance } \\
\text { Term }\end{array}$ & $\begin{array}{c}\text { Calc'd } \\
\text { Saturation } \\
\text { Conc. } \\
\text { Variance } \\
\text { Term }\end{array}$ & $\begin{array}{c}\text { Mass } \\
\text { Transfer } \\
\text { Coeff. } \\
\text { Variance } \\
\text { Term } \\
\end{array}$ & \begin{tabular}{|c|} 
Upper \\
Estimate w/ \\
$95 \%$ \\
confidence \\
(m2)
\end{tabular} & $\begin{array}{c}\text { Surface } \\
\text { Area }>1 \\
\text { m2 ? }\end{array}$ \\
\hline C103 & May-94 & $17.0^{\circ}$ & 1462.72 & 608.4 & 1.8 & -16 & Yes & $1.0 \mathrm{E}+02$ & $3.1 \mathrm{E}+00$ & $1.9 \mathrm{E}+01$ & $1.1 \mathrm{E}+01$ & 3 & Yes \\
\hline 6107 & $9 / 29 / 94$ & 17.0 & 5.90 & 1097.0 & 2.0 & 0.05 & & $7.9 E-04$ & $4.8 \mathrm{E}-05$ & $3.0 \mathrm{E}-04$ & $8.4 \mathrm{E}-05$ & 0.10 & \\
\hline C107 & $1 / 17196$ & 17.0 & 3.08 & 792.3 & 1.9 & 0.04 & & $4.6 \mathrm{E}-04$ & $2.8 \mathrm{E}-05$ & $1.8 \mathrm{E}-04$ & $5.0 \mathrm{E}-05$ & 0.08 & \\
\hline C107 & $3 / 26 / 96$ & 17.0 & 2.39 & 696.5 & 1.8 & 0.03 & & $3.8 \mathrm{E}-04$ & $2.3 \mathrm{E}-05$ & $1.5 \mathrm{E}-04$ & $4.1 \mathrm{E}-05$ & 0.07 & \\
\hline 0107 & $9 / 5 / 96$ & 17.0 & 2.91 & 893.0 & 1.9 & 0.03 & & $3.1 \mathrm{E}-04$ & $1.9 \mathrm{E}-05$ & $1.2 \mathrm{E}-04$ & $3.3 \mathrm{E}-05$ & 0.06 & \\
\hline 0107 & $12 / 17 / 96$ & 17.0 & 3.32 & 780.4 & 1.9 & 0.04 & & $5.6 \mathrm{E}-04$ & $3.4 \mathrm{E}-05$ & $2.1 \mathrm{E}-04$ & $6.0 \mathrm{E}-05$ & 0.09 & \\
\hline $\mathrm{C} 107$ & $2 / 7 / 97$ & 17.0 & 3.22 & 635.2 & 1.8 & 0.05 & & $8.8 \mathrm{E}-04$ & $5.4 \mathrm{E}-05$ & $3.3 \mathrm{E}-04$ & $9.4 \mathrm{E}-0.5$ & 0.11 & \\
\hline C108 & $8 / 5 / 94$ & 17.0 & 1.25 & 203.8 & 1.2 & 0.09 & & $2.8 \mathrm{E}-03$ & $1.7 \mathrm{E}-04$ & $1.0 \mathrm{E}-03$ & $2.9 \mathrm{E}-04$ & 0.19 & \\
\hline C109 & $8 / 10 / 94$ & 17.0 & 1.60 & 248.3 & 1.3 & 0.08 & & $2.6 \mathrm{E}-03$ & $1.6 \mathrm{E}-04$ & $9.8 \mathrm{E}-04$ & $2.8 \mathrm{E}-04$ & 0.19 & \\
\hline ct1o & $8 / 18 / 94$ & 17.0 & 16.73 & 159.4 & 1.1 & 1.83 & Yes & $1.3 \mathrm{E}+00$ & $9.5 \mathrm{E}-02$ & $5.9 \mathrm{E}-01$ & $1.3 \mathrm{E}-01$ & 4.2 & Yes \\
\hline $\mathrm{C} 111$ & $9 / 13 / 94$ & 17.0 & 1.07 & 236.0 & 1.3 & 0.06 & & $1.3 \mathrm{E}-03$ & $8.0 \mathrm{E}-05$ & $5.0 \mathrm{E}-04$ & $1.4 \mathrm{E}-04$ & 0.13 & \\
\hline ci12 & 811194 & 17.0 & 5.57 & 2703 & $1: 4$ & 0.26 & & $2.5 E-02$ & $1.6 \mathrm{E}-03$ & $9.9 \mathrm{E}-03$ & $2.7 \mathrm{E}-03$ & 0.59 & \\
\hline $\mathrm{C} 201$ & $6 / 19 / 96$ & 170 & 5.83 & 86.3 & 0.7 & 1.69 & Yes & $1.1 \mathrm{E}+00$ & $7.4 \mathrm{E}-02$ & 4.6E-01 & 1.1E-01 & 3.8 & Yes \\
\hline $\mathrm{C} 202$ & $6 / 25 / 96$ & 17.0 & 2.30 & 95.7 & 0.8 & 0.53 & & $1.0 \mathrm{E}-01$ & $6.6 \mathrm{E}-03$ & 4. $1 E-02$ & $1.1 \mathrm{E}-02$ & 1.19 & Yes \\
\hline C204 & $7 / 2 / 96$ & 170 & 174.32 & 110.0 & 0.9 & -53 & Yes & $1.0 E+03$ & $1.8 \mathrm{E}+02$ & $1.1 \mathrm{E}+03$ & $1.1 E+02$ & 29.43 & Yes \\
\hline S101 & $6 / 6 / 96$ & 17.0 & 12.86 & 330.2 & 1.5 & 0.47 & & $8.1 \mathrm{E}-02$ & $5.3 \mathrm{E}-03$ & $3.3 \mathrm{E}-02$ & $8.7 \mathrm{E}-03$ & 1.06 & Yes \\
\hline$\$ 102$ & $3 / 14 / 95$ & 17.0 & 0.55 & 1952 & -12 & 0.040 & & $6.1 \mathrm{E}-04$ & $3.7 \mathrm{E}-05$ & $2.3 \mathrm{E}-04$ & $6.5 \mathrm{E}-05$ & 0.09 & \\
\hline $\mathrm{S} 102$ & $1 / 26 / 96$ & 17.0 & 0.44 & 122.8 & 0.9 & 0.065 & & $1.6 \mathrm{E}-03$ & $9.7 E-05$ & $6.1 \mathrm{E}-04$ & $1.7 \mathrm{E}-04$ & 0.15 & \\
\hline S102 & $4 / 4 / 96$ & 17.0 & 0.44 & 177.3 & 1.1 & 0.037 & & $5.0 \mathrm{E}-04$ & $3.1 \mathrm{E}-05$ & $1.9 \mathrm{E}-04$ & $5.4 \mathrm{E}-05$ & 0.08 & \\
\hline 5102 & $9 / 19 / 96$ & 17.0 & 0.73 & 281.9 & 1.4 & 0.032 & & $3.8 \mathrm{E}-04$ & $2.3 \mathrm{E}-05$ & $1.4 \mathrm{E}-04$ & $4.0 \mathrm{E}-05$ & 0.07 & \\
\hline$\$ 102$ & $12 / 19 / 96$ & 17.0 & 0.46 & 234.0 & 1.3 & 0.026 & & $2.5 \mathrm{E}-04$ & $1.5 \mathrm{E}-05$ & $9.4 \mathrm{E}-05$ & $2.7 \mathrm{E}-05$ & 0.06 & \\
\hline 5102 & $2 / 1+197$ & 17.0 & 0.53 & 168.1 & 1.1 & 0.048 & & $8.7 E-04$ & $5.3 \mathrm{E}-05$ & $3.3 \mathrm{E}-04$ & $9.3 \mathrm{E}-05$ & 0.11 & \\
\hline$\$ 103$ & $6 / 12 / 96$ & 17.0 & 0.77 & 169.6 & 1.1 & 0.07 & & $1.8 \mathrm{E}-03$ & $1.1 \mathrm{E}-04$ & $6.7 \mathrm{E}-04$ & $1.9 \mathrm{E}-04$ & 0.16 & \\
\hline 5105 & $12 / 7 / 95$ & 17.0 & 2.46 & 156.6 & 1.1 & 0.25 & & $2.4 \mathrm{E}-02$ & $1.5 \mathrm{E}-03$ & $9.2 \mathrm{E}-03$ & $2.5 \mathrm{E}-03$ & 0.57 & \\
\hline 5106 & $6 / 13 / 96$ & 17.0 & 1.97 & 123.9 & 0.9 & 0.29 & & $3.2 \mathrm{E}-02$ & $2.0 \mathrm{E}-03$ & $1.2 \mathrm{E}-02$ & $3.4 \mathrm{E}-03$ & 0.66 & \\
\hline S107 & $6 / 18 / 96$ & 17.0 & 6.34 & 240.0 & 1.3 & 0.35 & & $4.6 \mathrm{E}-02$ & $2.9 \mathrm{E}-03$ & $1.8 \mathrm{E}-02$ & $4.9 \mathrm{E}-03$ & 0.80 & \\
\hline$\$ 108$ & $12 / 6 / 95$ & 17.0 & 2.36 & 162.3 & 1.1 & 0.23 & & $1.9 \mathrm{E}-02$ & $1.2 E-03$ & $7.5 \mathrm{E}-03$ & $2.1 \mathrm{E}-03$ & 0.52 & \\
\hline 5109 & $6 / 4 / 96$ & 17.0 & 3.38 & 120.6 & 0.9 & 0.53 & & $1.0 \mathrm{E}-01$ & $6.7 \mathrm{E}-03$ & 4.1E-02 & $1.1 \mathrm{E}-02$ & 1.20 & Yes \\
\hline S110 & $12 / 5 / 95$ & 17.0 & 3.42 & 232.0 & 1.3 & 0.20 & & $1.4 \mathrm{E}-02$ & $9.0 \mathrm{E}-04$ & $5.6 \mathrm{E}-03$ & $1.5 \mathrm{E}-03$ & 0.44 & \\
\hline$S+11$ & $3 / 21 / 95$ & 17.0 & 1.78 & 152.5 & 1.1 & 0.19 & & $1.3 \mathrm{E}-02$ & $8.3 E-04$ & $5.2 \mathrm{E}-03$ & $1.4 \mathrm{E}-03$ & 0.43 & \\
\hline$\$ 112$ & $7 / 11 / 95$ & 17.0 & 0.07 & 134.5 & 1.0 & 0.01 & & $3.4 \mathrm{E}-05$ & $2.1 E-06$ & $1.3 \mathrm{E}-05$ & $3.6 \mathrm{E}-06$ & 0.02 & \\
\hline$T 104$ & $2 / 7 / 96$ & 17.0 & 1.79 & 79.3 & 0.7 & 0.58 & & $1.2 \mathrm{E}-0 \mathrm{t}$ & $7.95-03$ & $4.9 E-02$ & $1.3 \mathrm{E}-02$ & 1.31 & Yes \\
\hline$T 107$ & $1 / 1 8 \longdiv { 9 5 }$ & 17.0 & 3.58 & 106.0 & 0.9 & 0.70 & & $1.8 \mathrm{E}-01$ & $1.2 \mathrm{E}-02$ & $7.3 \mathrm{E}-02$ & $1.9 \mathrm{E}-02$ & 1.58 & Yes \\
\hline$T 110$ & $8 / 31 / 95$ & 17.0 & 1.03 & 118.4 & 0.9 & 0.16 & & $9.8 \mathrm{E}-03$ & $6.0 \mathrm{E}-04$ & $3.8 \mathrm{E}-03$ & $1.3 \mathrm{E}-03$ & 0.37 & \\
\hline$T 111$ & $1 / 20 / 95$ & 17.0 & 20.94 & 88.0 & 0.7 & 7.2 & Yes & $1.9 E+01$ & 2.0 & $1.2 E+01$ & $2.1 \mathrm{E}+00$ & 17.02 & Yes \\
\hline TX104 & $5 / 5 / 97$ & 17.0 & 1.39 & 86.3 & 0.7 & 0.381 & & $5,4 E-02$ & $3.4 \mathrm{E}-03$ & $2.1 \mathrm{E}-02$ & $5.8 \mathrm{E}-03$ & 0.86 & \\
\hline$T \times 105$ & $12 / 20194$ & 17.0 & 4.60 & 205.6 & 1.2 & 0.32 & & $3.7 \mathrm{E}-02$ & $2.4 \mathrm{E}-03$ & $1.5 \mathrm{E}-02$ & $4.0 \mathrm{E}-03$ & 0.71 & \\
\hline TX106 & $3 / 5 / 97$ & 17.0 & 5.62 & 113.1 & 0.9 & 1.00 & & $3.7 \mathrm{E}-01$ & $2.5 \mathrm{E}-02$ & $1.6 \mathrm{E}-01$ & $4.0 \mathrm{E}-02$ & 2.27 & Yes \\
\hline$T \times 111$ & $10 / 12 / 95$ & 17.0 & 0.60 & 129.7 & 1.0 & 0.08 & & $2.5 \mathrm{E}-03$ & $1.5 \mathrm{E}-04$ & $9.4 \mathrm{E}-04$ & 2.7E-04 & 0.18 & \\
\hline$T \times 113$ & $8 / 6 / 97$ & 17.0 & 0.08 & 112.1 & 0.9 & 0.01 & & $6.5 \mathrm{E}-05$ & $3.9 \mathrm{E}-06$ & $2.5 \mathrm{E}-05$ & $7.0 E-06$ & 0.03 & \\
\hline $7 \times 114$ & $3 / 25 / 97$ & 17.0 & 1.26 & 96.6 & 0.8 & 0.28 & & $3.0 \mathrm{E}-02$ & $1.9 \mathrm{E}-03$ & $1.2 \mathrm{E}-02$ & $3.2 \mathrm{E}-03$ & 0.64 & \\
\hline IX116 & $9 / 18197$ & 170 & 0.65 & 471 & 10 & 007 & & $20 \mathrm{E} 03$ & $12 E-64$ & $64 E=4$ & $421 E 04$ & 0.16 & \\
\hline$T \times 118$ & $12 / 16 / 94$ & 17.0 & 1.29 & 153.9 & 1.1 & 0.13 & & $6.8 \mathrm{E}-03$ & $4.2 E-04$ & $2.6 E-03$ & $7.3 \mathrm{E}-04$ & 0.30 & \\
\hline TY101 & $4 / 695$ & 17.0 & 1.47 & 89.7 & 0.8 & 0.38 & & $5.3 \mathrm{E}-02$ & $3.3 \mathrm{E}-03$ & $2.3 \mathrm{E}-02$ & $5.7 \mathrm{E}-03$ & 0.85 & \\
\hline TY102 & $4 / 12 / 96$ & 17.0 & 0.90 & 74.9 & 0.6 & 0.32 & & 3.9E-02 & $2.4 \mathrm{E}-03$ & $1.5 \mathrm{E}-02$ & $4.1 \mathrm{E}-03$ & 0.73 & \\
\hline TY103 & $4 / 11 / 95$ & 17.0 & 58.48 & 92.2 & 0.8 & 38 & Yes & $5.5 \mathrm{E}+02$ & $2.5 \mathrm{E}+02$ & $1.5 \mathrm{E}+03$ & $5.9 \mathrm{E}+01$ & 119.00 & Yes \\
\hline TY103 & $11 / 22 / 96$ & 17.0 & 74.11 & 117.3 & 0.9 & 31.96 & Yes & $3.8 \mathrm{E}+02$ & $1.7 \mathrm{E}+02$ & $1.1 \mathrm{E}+03$ & $4.1 E+01$ & 99.03 & Yes \\
\hline TY104 & $4 / 2 7 \longdiv { 9 5 }$ & 17.0 & 2.84 & 957 & 0.8 & 0.66 & & $1.6 \mathrm{E}-01$ & $1.0 E-02$ & $6.4 \mathrm{E}-02$ & $1.7 \mathrm{E}-02$ & 1.48 & Yes \\
\hline $\mathrm{U} 103$ & $2 / 15 / 95$ & 17.0 & 0.42 & 158.0 & 1.1 & 0.04 & & 6.5E-04 & $4.0 \mathrm{E}-05$ & $2.5 \mathrm{E}-04$ & $7.0 E-05$ & 0.09 & \\
\hline
\end{tabular}


DISTRIBUTION SHEET

\begin{tabular}{|c|c|c|c|c|c|}
\hline \multirow{2}{*}{$\begin{array}{l}\text { To } \\
\text { Distribution }\end{array}$} & \multirow{2}{*}{\multicolumn{3}{|c|}{$\begin{array}{l}\text { From } \\
\text { Process Control }\end{array}$}} & \multicolumn{2}{|c|}{ Page 1 of 1} \\
\hline & & & & \multicolumn{2}{|c|}{ Date $9 / 30 / 98$} \\
\hline \multicolumn{4}{|l|}{ Project Title/Work Order } & \multicolumn{2}{|c|}{ EDT No. 625030} \\
\hline Rotary Mode Core Samp 1 i & ed Checklist: & $41-T X-11$ & & \multicolumn{2}{|c|}{ ECN No. NA } \\
\hline Name & MSIN & $\begin{array}{c}\text { Text } \\
\text { With All } \\
\text { Attach. }\end{array}$ & Text Only & $\begin{array}{c}\text { Attach./ } \\
\text { Appendix } \\
\text { Only }\end{array}$ & $\begin{array}{l}\text { EDT/ECN } \\
\text { Only }\end{array}$ \\
\hline
\end{tabular}

ONSITE

Lockheed Mart in Hanford, Corp.
W. B. Barton
R2-12 X X
V. C. Boyles
R. N. Dale
R2-11
$57-12$
S. D. Estey
R2-11
$57-12$
T. R. Farris
K. D. Fowler
T. A. $\mathrm{Hu}$
R2-11
R2-11
R2-11
R2-12
J. G. Kristofzski
D. J. Mccain
J. S. Schofield
R2-12
$57-12$
L. A. Stauffer
R2-11
T. C. S. R. C.
$R 1-10$
$X$
$X$
$X$
$X$
$X$
$X$
$X$
$X$
$X$
$X$
$X$
$X$
$X$

Lockheed Mart in Services, Inc. 